This item was submitted to Loughborough's Research Repository by the author.

Items in Figshare are protected by copyright, with all rights reserved, unless otherwise indicated.

\title{
On Great Hungary and the importance of minor geopolitical traditions
}

PLEASE CITE THE PUBLISHED VERSION

http://dx.doi.org/10.1016/j.polgeo.2012.10.005

\section{PUBLISHER}

(c) Elsevier Ltd.

\section{VERSION}

AM (Accepted Manuscript)

\section{PUBLISHER STATEMENT}

This work is made available according to the conditions of the Creative Commons Attribution-NonCommercialNoDerivatives 4.0 International (CC BY-NC-ND 4.0) licence. Full details of this licence are available at: https://creativecommons.org/licenses/by-nc-nd/4.0/

\section{LICENCE}

CC BY-NC-ND 4.0

\section{REPOSITORY RECORD}

Antonsich, Marco, and Kinga Szalkai. 2019. "On Great Hungary and the Importance of Minor Geopolitical Traditions". figshare. https://hdl.handle.net/2134/16080. 


\title{
On Great Hungary and the importance of minor geopolitical traditions
}

\author{
Marco Antonsich \\ Department of Geography \\ Loughborough University \\ Loughborough, Leicestershire \\ LE11 3TU \\ United Kingdom \\ EMAIL: M.Antonsich@lboro.ac.uk
}

\section{Kinga Szalkai}

Corvinus University of Budapest

Doctoral School of International Relations

8 Fővám tér

Budapest, 1093

Hungary

EMAIL: szalkai.kinga87@googlemail.com

It's a Monday morning of a hot summer day in Budapest. A well-dressed, old lady climbs the stairs of the Trolley Bus 75, in the centre of Pest. She sits besides another woman, also well-dressed, in her early forties. A polite conversation starts about the hot weather and the catastrophes that it causes. When the younger lady observes that Hungary, in general, has very favourable climate conditions, her interlocutor abruptly replies:

"Yes, this is why so many nations envy us!" 
"Why, is it because we recovered from so many tragedies and catastrophes?"

"No, I mean Hungary has always been attacked because our forefather Árpád had a perfect choice with this country. This is why Hungary fought through so many centuries, and this is why many people died and Hungary got divided. This beautiful huge country, just imagine how beautiful it was! [and then] Trianon came"

\section{“Mmmmm, mmmm"}

"And this country is a total disaster since then! They took away what they could $[\ldots] "$

More than ninety years have passed since the Treaty of Trianon (1920), which left Hungary with less than a third of its original territory and about 3.3 million ethnic Hungarians living in the neighbouring countries of then Romania, Czechoslovakia, and the Kingdom of Serbs, Croats and Slovenes. Yet, Trianon and the idea of Great Hungary are far from being relics of the past. They can commonly surface in daily conversations, enter the political debate, or even find expressions in artistic installations, like the controversial giant carpet inaugurated in January 2011, in Brussels, to mark Hungary's EU rotating presidency, featuring among others a map of Great Hungary. ${ }^{1}$

Trianon is still present in Hungarian collective consciousness because since then the argument simplistically goes - the borders of the country no longer match the borders of the nation. This certainly is not a unique case in the world. Yet, we contend that to pay attention to the ways in which the notion of Great Hungary was discursively constructed allows for a perspective on geopolitics different from the one traditionally encountered in the Anglo-American geopolitical traditions. In the case of Hungary, geopolitics - and, in particular, its environmental determinist variant - was not deployed as a tool of imperialism and territorial expansionism, but as a discourse legitimizing the existing borders of the state. In other words, it was not outward, but inward oriented, resembling 
in some aspects the ways it featured in another minor geopolitical tradition (Hepple, 1986). Here below we shall briefly look into the Hungarian geopolitical tradition to substantiate this point.

On the eve of the Trianon peace talks, a group of Hungarian academics published an appeal to the negotiators for preserving the territorial unity of Great Hungary (Polner et al., 1918). Their main argument was "the so-called principle of geopolitics (geopolitika)", according to which stable states' formation relies on areas which belong together geographically and thus are interconnected economically. Only states based on permanent natural circumstances can survive throughout history, whereas "national belonging" (i.e. the principle of nationality) can only provide an "intellectual connection" which will never be permanent. Thus, on the table of the peace conference - the authors claimed - "we should not lay the map of nationalities, but the oro- and hydrographic map" (Polner et al., 1918: 10, 14-15).

The construction of Great Hungary as a geographical unity defined by the natural borders of the Carpathian basin had already come to the fore in the second half of the nineteenth century, thanks in particular to the work of János Hunfalvy (1863-1865), the father of Hungarian geographical science and founder of the Hungarian Geographical Society (1872). Yet, in the years before and after Trianon, Hungarian geographers gave further substance to this idea as a way to defend first and to reclaim later the territorial unity of the country. According to one of the main experts on the history of Hungarian geography, it was indeed during the preparation for the peace process at Versailles when modern Hungarian geography developed (Hajdú, 2000; Hajdú, 2001). Relying on the organicism of Carl Ritter and Friedrich Ratzel, eclectically mixed with ideas from Paul Vidal de la Blache, Elisée Reclus, Jean Brunhes, Eduard Suess, and William Morris Davis - all used to justify the importance of natural factors in shaping socio-economic life - Hungarian geographers produced a vast scholarship aimed at one single aim: to demonstrate the natural, organic unity of Great Hungary. Attempts were also made to convince foreign readers of such a unity, like the edited book by one of the most influential Hungarian geographers of the time, Lajos Lóczy (1918), translated in German and Croatian (English, French and Italian editions were also planned, but at the end could not be published) (Hajdú, 2000). The Hungarian Geographical Society (1918) also 
published an appeal to "the geographical societies of the world", and in particular to the ones of the victorious powers of World War I, defending once again the indivisibility of Great Hungary on the basis of the organic unity which people form with their natural habitat, irrespective of their ethnic and linguistic differences. To capture this organic unity, the notion of Lebensraum was at times also used, like in the case of the works of two of the most prominent Hungarian geographers of the interwar period - Gyula Prinz and Pál Teleki (the latter became Prime Minister twice, in 1920-21 and in 1939-41). Yet, this notion was adopted in relation to the internal space of the country, without any reference to the state's territorial growth - Great Hungary indeed as "a separate Lebensraum" (Prinz and Teleki, 1937: 30). While in the neighbouring countries, the notion of race was also increasingly used to support geopolitical discourses (Bassin 1987), it did not play a significant role in Hungarian geopolitics. Although there were clear references to the existence of a Hungarian race (Lóczy, 1918: 137-147) and the need for its protection (Kalmár 1942: 15-18), overall Great Hungary was not constructed in ethno-racial terms (Bartucz, 1938). This would have obviously questioned the unity of the country, although in 1920 Pál Teleki published for the peace talks in Versailles his ethnography map (Figure 1), showing the impossibility to draw clear ethno-cultural borders within Great Hungary. Rather than race, it was instead the notion of a unified orographic and hydrographic basin which constantly featured in the geopolitical discourses about Great Hungary: "Nature marked the borders of the Hungarian state as expressive, as sharply, that it does not need artificial delimitation, or red lines on maps, it can be recognized without them, exactly because it is not the outcome of human power relations, but of natural development" (Polner et al., 1918: 20) (Figure 3). The fact that the boundaries of the state only slightly changed since the time Árpád entered the Carpathian Basin and founded the first Hungarian state (895 A.D.) was a historical reference also frequently used to support the indivisibility of Great Hungary in name of 'one-thousand-years-old borders'.

After World War II, Trianon, Great Hungary and the fate of the so-called 'overborder Hungarians' were passed under silence (Ablonczy, 2007). These were to return again as central topics of the domestic political debate after the regime change, often exploited for electoral purposes by the conservative party Fidesz. Under its governments, 
a series of legal measures were adopted (status law, citizenship law, and electoral law), all aimed at empowering the rights of over-border Hungarians. Moreover in 2011, the Fidesz government promulgated the new Constitution, whose article D expressly acknowledges "the ideal of a unified Hungarian nation" and reiterates Hungary's "responsibility for the destiny of Hungarians living outside her borders" - a principle already codified into the Hungarian constitution after the regime change.

Besides these political and juridical acts, today the idea of Great Hungary continues to be present in various aspects of everyday life. T-shirts, pins, refrigerator magnets, posters, key-holders, mugs, bumper-stickers, wrist-bands, football scarfs, pillow cases, and puzzles are among the most common and banal (Billig, 1995) items displaying the image of Great Hungary (Figure 2-3). This obviously points to its commodification - its exploitation for commercial purposes, besides for electoral interests. Labelling food, clothes, and other products as coming from the 'over-border-territories' is a popular marketing strategy nowadays. This was also true during the interwar period, when the political rhetoric condemning Trianon found expression not only in official commemorations, monuments, and the changing of street toponyms to remember the 'lost' territories (Borbély Bartis and Borbély Bartis, 2009); but also in countless everyday objects: lockets, plates, soda bottles, ashtrays, pencil boxes, postcards, wall carpets, children board-games, cards, etc. (Figure 4) (Zeidler, 2002).

According to a survey administered by a group of Hungarian academics (ELTE, 2010), the map of Great Hungary is listed high (3.7 on a 1 to 5 scale) among the items which represent Hungary the most and, not surprisingly, the Treaty of Trianon is on the top of the list of "Hungary's historical national tragedies". School atlases continue to reproduce the historical map of Great Hungary, hinting at the natural unity of its space (Figure 5). Towns which are now in neighbouring countries continue to be called with Hungarian toponyms, as a quick look at road atlases or Wikipedia would reveal. Thus, for instance, Bratislava is Pozsony and Cluj-Napoca is Kolozsvár and they are known as such by the Hungarian general public. Watching the weather forecast on any of the Hungarian state TV channels today can still be a fascinating geopolitical experience, with Great Hungary coming into being through weather icons (Figure 6). 
Although almost a century has passed since Trianon, Great Hungary is still part of Hungarians' memory and imaginary, feeding and being fed by the 'natural unity' discourse. By briefly surveying the way in which this geopolitical idea has been reproduced, this editorial has attempted to underline the importance of moving away from mainstream geopolitical traditions. This move would not only fulfil the promise of critical geopolitics to open up the terrain for 'other' voices, but it would also contribute as recently discussed in this journal (Moisio et al., 2011) - to explore the numerous ways in which geopolitics can be bended to adapt to specific regional and historical contexts, thus exposing its semantic plurality and malleability.

\section{References}

Ablonczy, B. (2007). Trianon-problémák. Kommentár, 4, 57-67.

Bartucz, L. (1938). A magyar ember. Budapest: Egyetemi Nyomda.

Bassin, M. (1987). Race contra space: the conflict between German Geopolitik and National Socialism. Political Geography Quarterly, 6(2), 115-134.

Billig, M. (1995). Banal nationalism. London: Sage.

Borbély Bartis, J., \& Borbély Bartis, E. (2009). Budapest. Budapest: Közdok.

ELTE (2010). Nemzeti tudat, nemzeti tragédiák. ELTE. Available at http://konfliktuskutato.hu/index.php?option=com_content \&view=article\&id=276:n emzeti-tudat-nemzeti-tragediak\&catid=32:konfliktusmonitoring (accessed 11/09/2012). 
Hajdú, Z. (2000). A magyar földrajztudomány és a trianoni békeszerződés.

Kisebbségkutatás, 2, 224-233.

Hajdú, Z. (2001) The influence of Friedrich Ratzel on Hungarian geography. In Antonsich, M., Kolossov, V. \& M.P. Pagnini (Eds) Europe between political geography and geopolitics (pp.129-143). Roma: Società Geografica Italiana, 2001.

Hepple, L.W. (1986). Geopolitics, generals and the state in Brazil. Political Geography Quarterly, S5, S79-S90.

Hunfalvy, J. (1863-1865). A magyar birodalom természeti viszonyainak leirása. Pest: Emich Gusztáv.

Kalmár, G. (1942). Magyar geopolitika. Budapest: Stádium.

Lóczy, L. (Ed.), (1918). A Magyar Szent Korona Országainak földrajzi, társadalomtudományi, közmüvelödési és közgazdasági leírása. Budapest: Kilián.

Magyar Földrajzi Társaság (1918). A Magyar Földrajzi Társaság szózata a világ Földrajzi Társaságaihoz. Földrajzi Közlemények, XLVI, 7-10, 289-320.

Moisio, S., Stokke, K., Sæther, E., Gutzon Larsen H., Ek, R., \& Hanse, A.L. (2011). Interventions in Nordic political geographies. Political Geography, 30, 241-249.

Polner, Ö., Kováts, F., Hodinka, A., Prinz, Gy., \& Lukinich, I. (1918). Pro Hungaria. Pozsony: Pozsonyi Magyar Tudományegyetem.

Prinz, Gy., \& Teleki, P. (1937). A magyar munka földrajza. Budapest: Egyetemi Nyomda. 
Zeidler, M. (2002). A magyar irredenta kultusz a két háború között. In Pásztor, C. (Ed.), „...ahol a határ elválaszt” (pp. 31-46). Balassagyarmat-Várpalota: Nagy Iván Történeti Kör.

Figure 1: Pál Teleki's ethnography map (also known as 'Red Map') (Source: Teleki, P. (1920). Magyarország néprajzi térképe a népsürüség alapján. Budapest: Klösz György és Fia Térképészeti Müintézet)

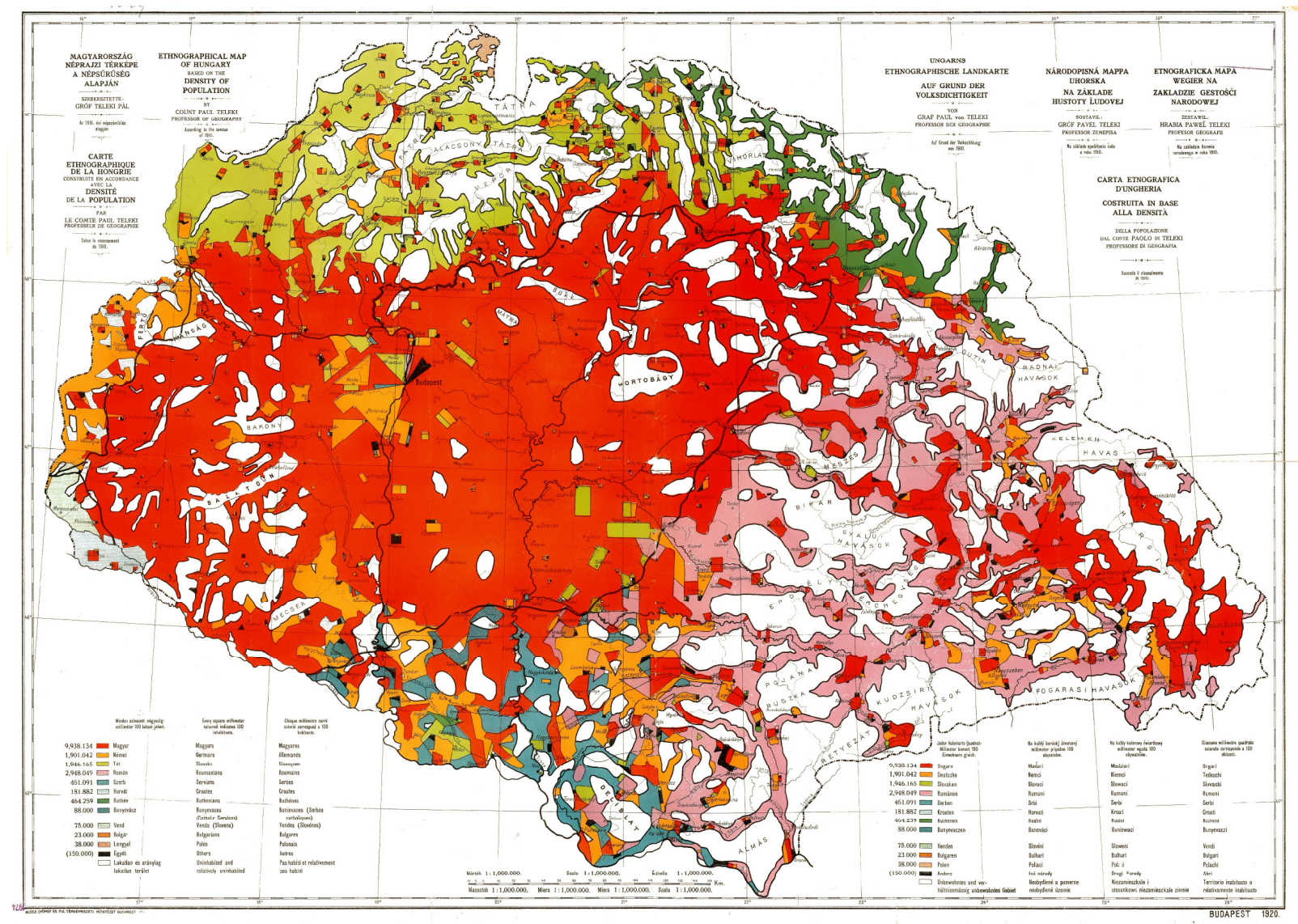

Figure 2, 3. Remembering Great Hungary

(Photo by Marco Antonsich) 

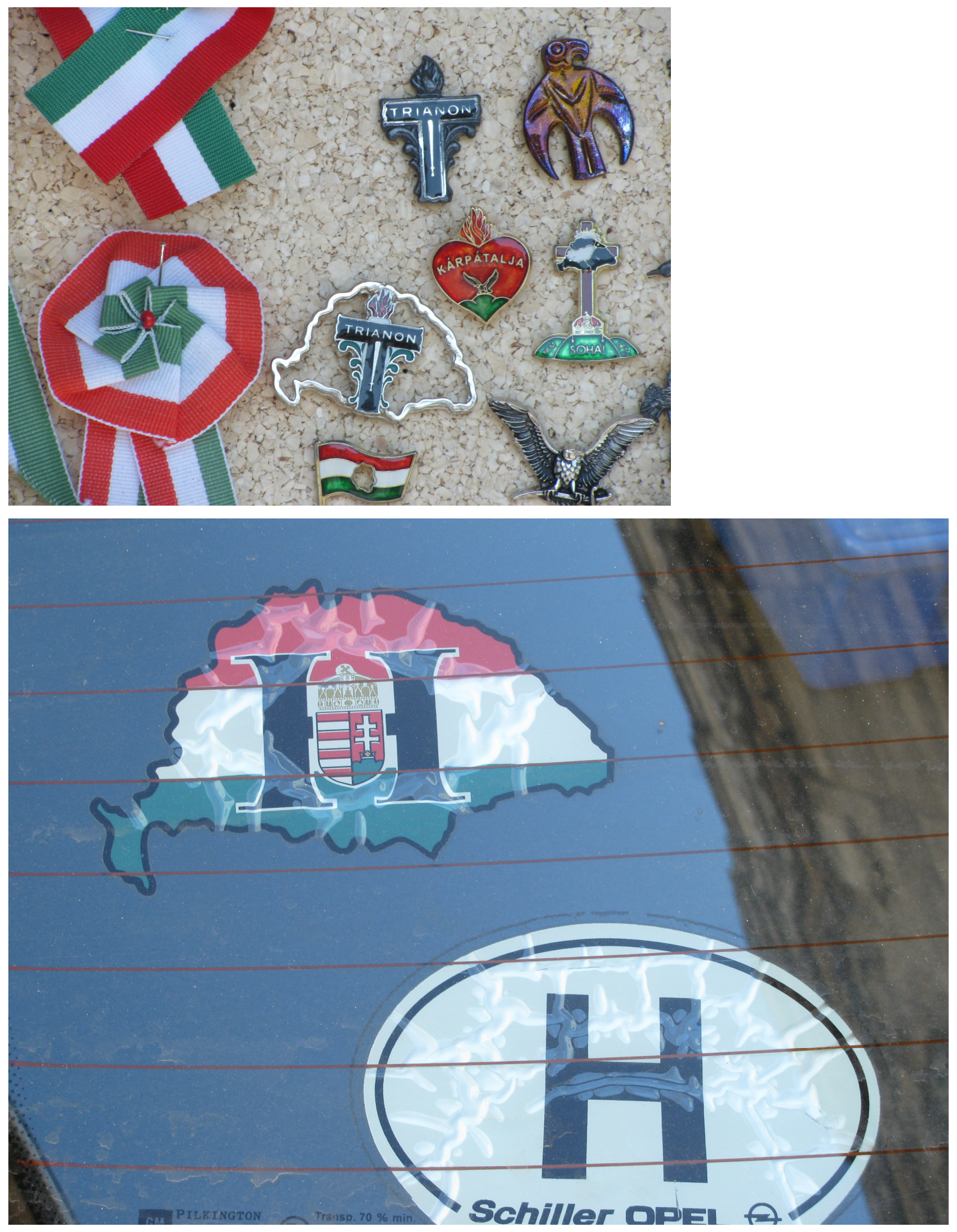
Figure 4. Pencil case from the interwar period. The print reads 'no, no, never' - three times 'no', as the name 'Trianon' was ironically translated by many Hungarians (Photo by Marco Antonsich).

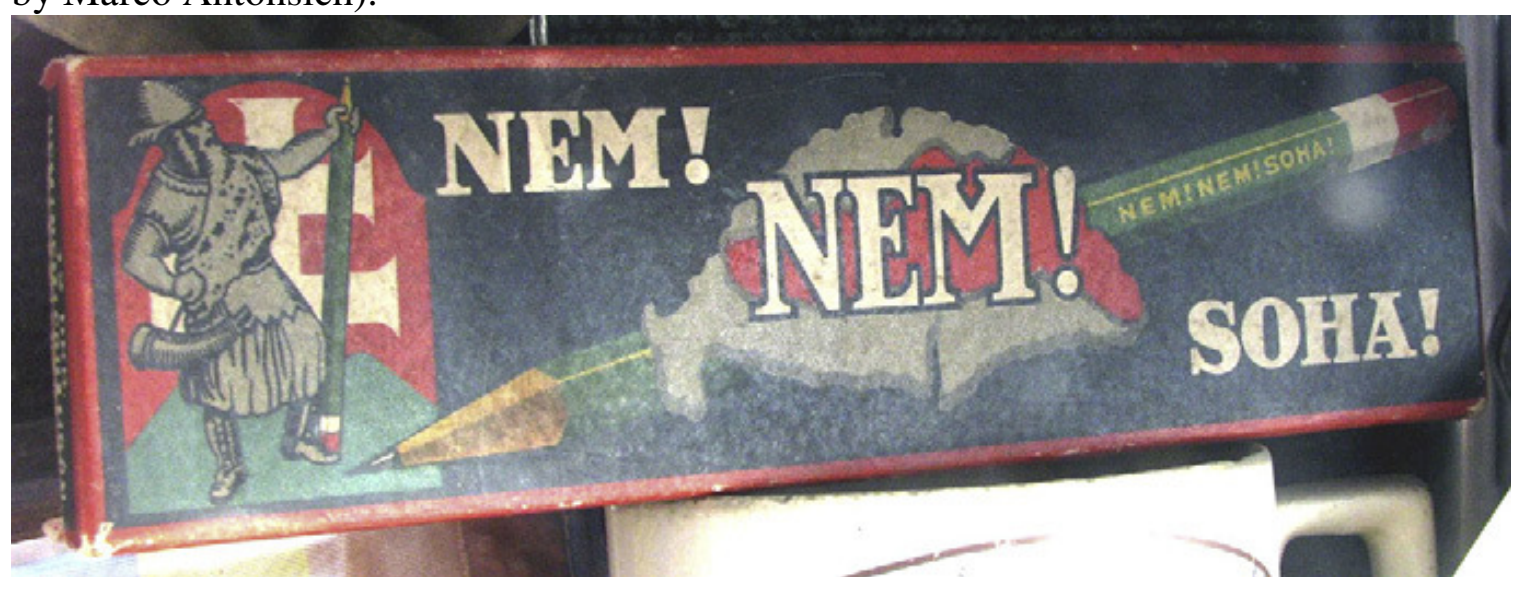

Figure 5. The 'natural unity' of the Carpathian Basin

(Source: Történelmi Világatlasz, Cartographia Tankönyvkiadó, 2007)

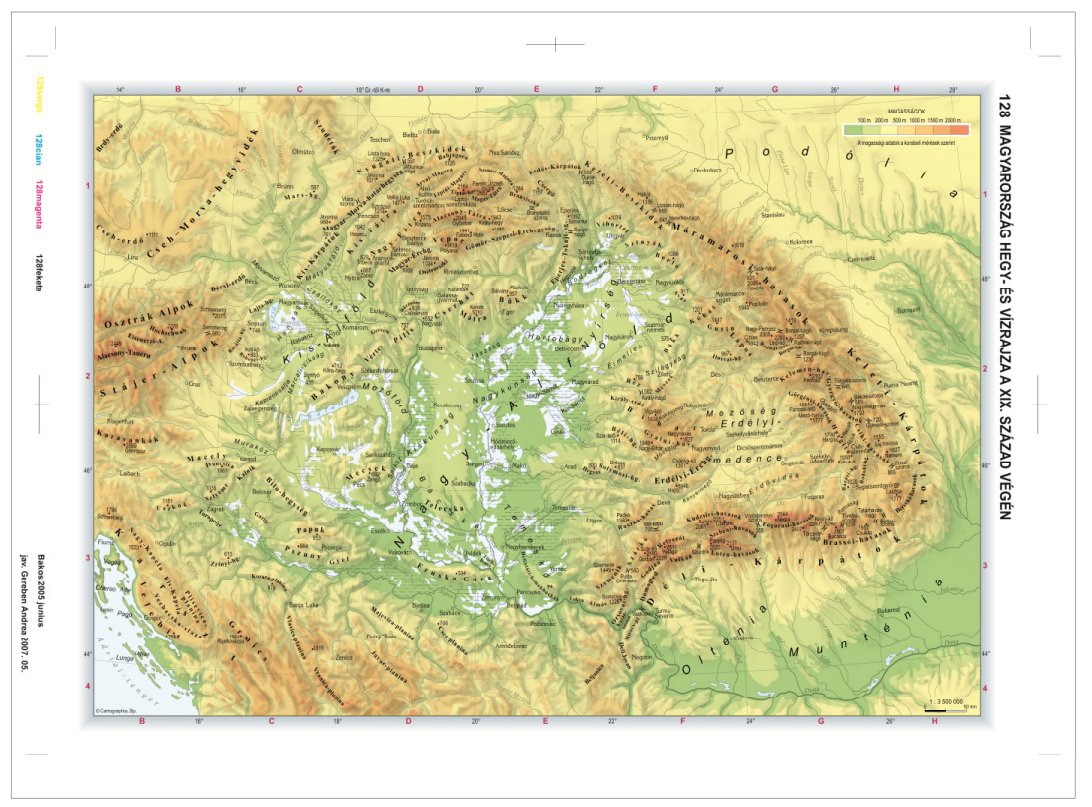

Figure 6. Great Hungary coming into shape again through the weather forecast on Hungary's state TV channels (Source: MTVA) 


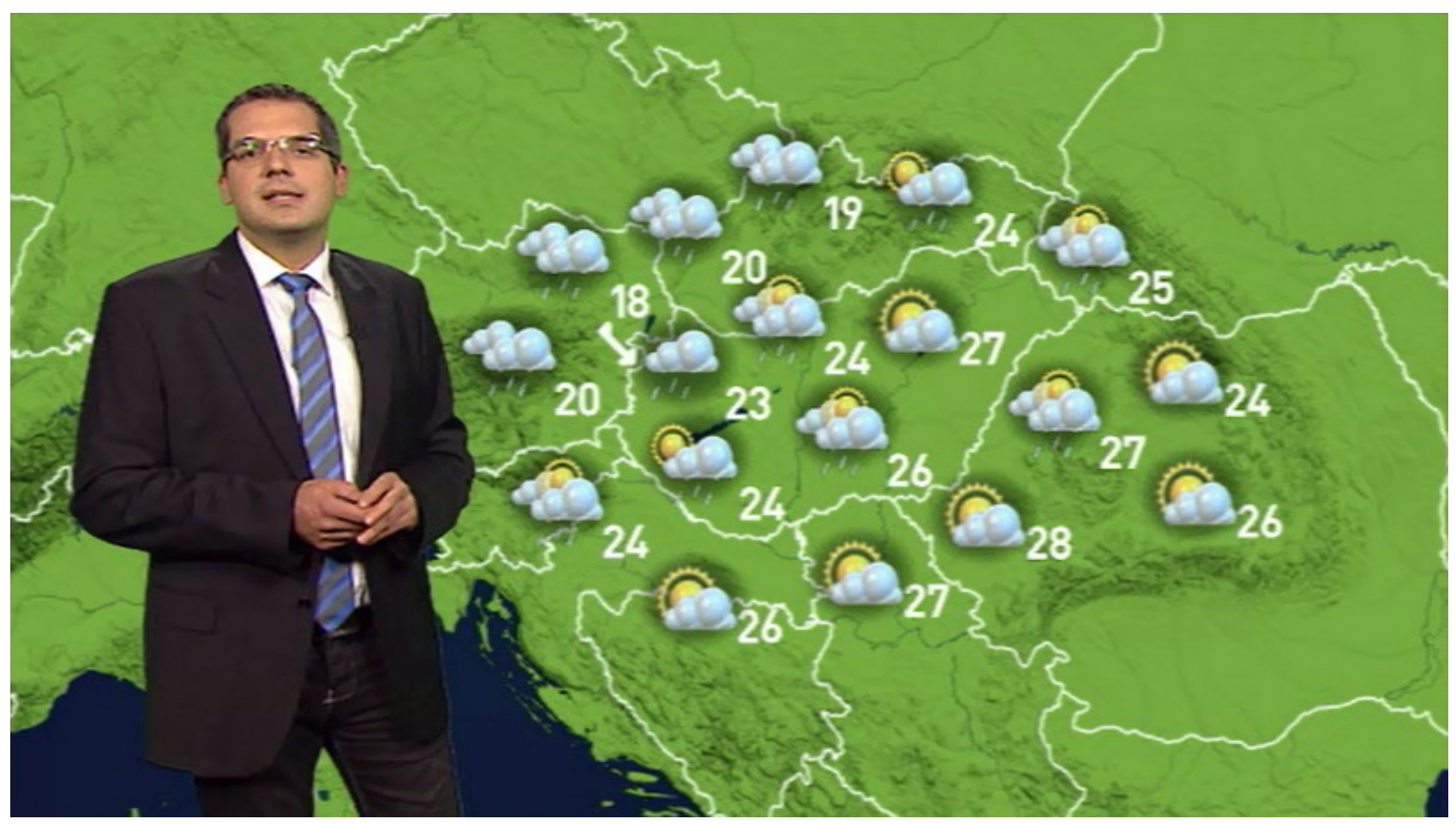

\footnotetext{
${ }^{1}$ See http://w3.externet.hu/ doborl/fot_newse.htm. This map was originally meant to link Hungary to the wave of revolutions which characterized Europe in 1848-49, i.e. a way to symbolize the common European heritage. Yet, it triggered the resentful reactions of Romanian, Slovak, and Austrian politicians, who saw in the map an attempt to question the Treaty of Trianon.
} 